\title{
PERSONAL HYGIENE AND ANTHELMINTIC CONSUMPTION IN PREVENTION OF ENTEROBIASIS AMONG PRIMARY SCHOOL CHILDREN
}

\section{Higiene Personal dan Konsumsi Obat Cacing pada Pencegahan Cacing Kremi pada Anak Usia Sekolah Dasar}

\author{
Ratna Muliawati ${ }^{1}$, Mushidah Mushidah ${ }^{2}$, Siti Musyarofah ${ }^{3}$ \\ ${ }^{1}$ Public Health Studies Program, Institutes of Health Sciences Kendal, r.moelia@gmail.com \\ ${ }^{2}$ Public Health Studies Program, Institutes of Health Sciences Kendal, hidnisa4@ gmail.com \\ ${ }^{3}$ Public Health Studies Program, Institutes of Health Sciences Kendal, sitimusyarofah24@gmail.com \\ Correspondence Author: Ratna Muliawati, r.moelia@gmail.com, Public Health Studies Program, Institutes of \\ Health Sciences, Jalan Laut No. 31, Kendal, Central Java, 51311, Indonesia
}

\section{ARTICLE INFO \\ Article History: \\ Received October, $10^{\text {th }}, 2019$ \\ Revised form October, $29^{\text {th }}, 2019$ \\ Accepted September, $13^{\text {th }}, 2020$ \\ Published online September, 20 ${ }^{\text {th }}, 2020$}

\section{Keywords: \\ annual deworming; \\ hand washing; \\ personal hygiene; \\ pinworm infection; \\ primary school students}

\section{Kata Kunci:}

konsumsi obat cacing tahunan;

kebiasaan mencuci tangan;

higiene personal;

infeksi cacing kremi;

anak sekolah dasar

\begin{abstract}
Background: Pinworm infection remains a global public health problem in Indonesia, with the highest prevalence in primary schoolaged children. The government has made helminthiasis control efforts through annual deworming every six months, yet data on the enterobiasis prevalence and its risk factors are still limited. Purpose: This research aimed to determine the role of personal hygiene and anthelmintic or worm medicine consumption in the prevention of enterobiasis among primary school children. Methods: This research employed an analytic observational method with a cross-sectional design. The population used was primary school children in the Public Health Center (PHC) of Kaliwungu area, Kendal District, Central Java Province. The research sample was 150 students from first grade to third grade at 1 Primary Elementary School 1 Kutoharjo. The data sources were obtained from interviews of risk factors and perianal swab examinations. The data were analyzed by a chi-square test and multiple logistic regression. Results: The prevalence of pinworm infection among primary school children remains high $(37.33 \%)$. The results of the multivariate analysis showed that there are three determinant variables of pinworm infections: not washing hands with soap before eating $(p<0.01$; Prevalence Odds Ratio $(\mathrm{POR})=6.47 ; 95 \%$ Confidence Interval $[\mathrm{CI}]$ $=2.87<$ POR < 14.59); not washing hands with soap after defecation $(p=0.01 ; \mathrm{POR}=3.36 ; 95 \% \mathrm{CI}=1.40<\mathrm{POR}<8.05)$; and not consuming anthelmintic drugs within the past six months $(p=0.03$; POR $=2.43 ; 95 \% \mathrm{CI}=1.08<\mathrm{POR}<5.50)$. Conclusion: Hand washing habits and annual deworming are important factors to prevent pinworm infections.
\end{abstract}

(C)2020 Jurnal Berkala Epidemiologi. Published by Universitas Airlangga. This is an open access article under CC-BY-SA license (https://creativecommons.org/licenses/by-sa/4.0/) 
How to Cite: Muliawati, R, Mushidah, M., \& Musyarofah, S. (2020). Personal hygiene and anthelmintic consumption in prevention of enterobiasis among primary school children. Jurnal Berkala Epidemiologi, 8(3), 265-274. https://dx.doi.org/10.20473/jbe.v8i320 20. $265-274$

\begin{abstract}
ABSTRAK
Latar belakang: Infeksi cacing kremi masih menjadi masalah kesehatan masyarakat di Indonesia dengan prevalensi tertinggi pada kelompok anak usia sekolah dasar. Pemerintah sudah melakukan upaya pengendalian kecacingan melalui pemberian obat cacing rutin setiap 6 bulan sekali, tetapi data prevalensi infeksi cacing kremi dan faktor risiko masih terbatas. Tujuan: Penelitian ini bertujuan untuk mengetahui kondisi higiene personal dan konsumsi obat cacing pada pencegahan cacing kremi pada anak usia sekolah. Metode: Penelitian ini merupakan penelitian observasional analitik dengan desain potong lintang. Populasi penelitian adalah anak usia sekolah dasar di wilayah kerja Puskesmas Kaliwungu, Kabupaten Kendal Provinsi Jawa Tengah. Sampel penelitian sejumlah 150 anak kelas 1-3 SDN 1 Kutoharjo Kaliwungu Kabupaten Kendal. Sumber data berasal dari wawancara data variabel higiene personal dan konsumsi obat cacing, serta pemeriksaan laboratorium. Data dianalisis menggunakan uji chi square dan multiple logistic regression. Hasil: Prevalensi infeksi cacing kremi pada anak usia sekolah dasar di wilayah kerja Kaliwungu sebesar 37,33\%. Hasil analisis multivariat menunjukkan bahwa ada tiga variabel yang secara bersama-sama menjadi faktor risiko infeksi cacing kremi adalah tidak mencuci tangan dengan sabun sebelum makan ( $p<0,01$; $P O R=6,47 ; 95 \% C I=2,87<P O R<14,59)$, tidak mencuci tangan dengan sabun setelah $B A B \quad(p=0,01 ; \quad P O R=3,36$; $95 \% C I=1,40<P O R<8,05)$, dan tidak minum obat cacing dalam 6 bulan terakhir $(p=0,03 ; \quad P O R=2,43 ; 95 \% C I=1,08<P O R<5,50)$. Kesimpulan: Kebiasaan mencuci tangan dan konsumsi obat cacing secara teratur dapat menjadi faktor penting dalam upaya pencegahan infeksi cacing kremi.
\end{abstract}

C2020 Jurnal Berkala Epidemiologi. Penerbit Universitas Airlangga. Jurnal ini dapat diakses secara terbuka dan memiliki lisensi CC-BY-SA (https://creativecommons.org/licenses/by-sa/4.0/)

\section{INTRODUCTION}

Pinworm infection or enterobiasis remains a global public health problem in both developed and developing countries (Berger, 2018; Hadidjaja \& Margono, 2011). According to Berger (2018), there are approximately 400 million people infected by pinworms worldwide, with the highest prevalence in the age group of 5-10 years. Research in several countries has shown a high prevalence of pinworm infections in children, including in Sri Lanka at 32\%-38\%, in Myanmar at $47.20 \%$, in Guangdong China at $45.96 \%$ $68,13 \%$, and in Iran at $22.2 \%$ (Ali et al., 2016; Chai et al., 2015; Li et al., 2015; Suraweera, Galgamuwa, Iddawela, \& Wickramasinghe, 2015).

According to Hadidjaja \& Margono (2011), the prevalence of pinworm infections in Indonesia is around $3 \%-80 \%$, with the highest prevalence in the five- to nine-years-old age group. Research conducted on children aged 6-12 years at Padang City Orphanage showed that $18 \%$ of the children were positively infected by pinworms (Pebriyani, Adrial, \& Nofita, 2019). The 5-12 years age group represents the preschool age group and elementary school age group. These groups are considered to not have good knowledge or awareness of maintaining cleanliness. In this age group, children often spend time playing outside the house, making direct contact with water and soil that could potentially trigger a pinworm infection (Anjarsari, 2018). Even though it infects children in relatively large numbers, pinworm infection has not obtained too much attention by the community. This is due to the fact that pinworm infection does not have the potential to cause death; thus, it has become one of the neglected diseases. According to Hadidjaja \& Margono (2011), most pinworm 
infections occur without significant symptoms, but some cases of pinworm infections can cause disturbing symptoms such as pruritas ani at night, causing children to experience insomnia, decreased appetite, and decreased body weight. Decreased appetite due to pinworm infections affects the nutritional status of children and results in growth and development disorders as well (Maryanti, Wahyuni, Ernalia, Haslinda, \& Lesmana, 2017).

Research in Turkey showed that children infected with worms have a risk of delay in both language development and fine motor development 1.90-2.90 times greater than those who are not infected (Doni, Zeyrek, Simsek, Gurses, \& Sahin, 2015). The Indonesian government has issued a policy on controlling helminthiasis in the form of clean and healthy living behavior promotion as well as mass administration of worm medication in February and August (Ministry of Health RI, 2017).

Several studies on the correlation of personal hygiene with pinworm infections have been carried out (Anjarsari, 2018; Chen, Yen, \& Hwang, 2018). However, there has been no research on the determinants of pinworm infections in primary school-aged children that includes elements of anthelmintic or worm medicine consumption that has been given by the government. Consumption of anthelmintic should be undertaken routinely as a preventative measure. According to Chai et al (2015), pinworm infections are easily recurring, and administration of worm medication cannot kill all eggs or pinworm larvae; thus, it is necessary to repeatedly administer worm medication. Cholifah (2016) discovered that the frequency of taking worm medication at least once every six months prevents transmission of pinworm infections.

Based on the description that was proposed previously, the research was undertaken to determine the determinants of pinworm infection. The working area of Public Health Center (PHC) of Kaliwungu, Kendal District, was chosen as the location of the study since there has not yet been research on the incidence of pinworm infection in the area. Information obtained during the preliminary study activities discovered that the PHC of Kaliwungu routinely distributes worm medication to the community according to government policies every February and August. There is a high risk of occurrence of pinworm infections in that area since there are plenty of soil and rice fields that are often used as playgrounds for children. This research aimed to determine the role of personal hygiene and consumption of worm medication in preventing pinworms in school-aged children.

\section{METHOD}

This research was an analytic observational study with a cross-sectional approach. The independent variables included personal hygiene and anthelmintic consumption, and the dependent variable (pinworm infection) was measured at the same time. The research was conducted in the working area of PHC of Kaliwungu, Kendal District.

The population was all primary school-aged children in the working area of PHC of Kaliwungu. The samples were taken using cluster sampling techniques in which researchers coordinated with PHC of Kaliwungu to determine elementary schools in their working areas as research sites. The selected elementary school was Public Elementary School 1 Kutoharjo, Kaliwungu, since the number of students at this elementary school was higher than that of any other elementary school. The researchers obtained student data from the selected elementary school. The number of samples in this study was 150 students in grade 1 to grade 3 of Public Elementary School 1 Kutoharjo, Kaliwungu, Kendal. These grades were considered as samples since all students in the age range of 6-10 years are the group with the highest prevalence of pinworm infections (Hadidjaja \& Margono, 2011).

The independent variable data were obtained through interviews using a questionnaire. The question items for the personal hygiene questionnaire included hand washing with soap before eating, hand washing with soap after defecating, hand washing with soap after playing with soil, habit of using soap in the shower, habit of cutting and caring for nails, habit of biting fingers, habit of sucking the fingers, the habit of scratching the buttocks area, habit of defecating in any place, and the consumption of an anthelmintic in the past six months.

The pinworm infection data were obtained through a microscopic examination to spot the presence of pinworm eggs on the nails and perianal area. The examination of fingernails was undertaken by cutting students' nails using nail clippers and accommodated in plastic pots. The nail samples were examined by the floating method using saturated $\mathrm{NaCl}$. The perianal smear examination was performed by the Graham scotch tape method. Each sample and perianal smear tape 
was labeled in the form of a student identification number. The sample examination was carried out in the Kendal School of Health Science laboratory by a team of researchers with a health analyst background. The respondents were considered as positive for pinworms if the results of their perianal smears found pinworm eggs.

The data were analyzed univariately and presented in the form of frequency distribution tables of the respondents' characteristics, which included their age, sex, habit of washing hands with soap before eating, habit of washing hands with soap after defecation, habit of washing hands with soap after playing with soil, habit of using soap when bathing, nail cutting habits, finger biting habits, finger sucking habits, habit of scratching the anal area, habit of defecating in any place, consumption of an anthelmintic in the past six months, the presence of worm eggs on fingernails, and the presence of worm eggs in the perianal area. This research fulfilled the research ethics requirements as proven by a letter issued by the Medical/Health Research Bioethics Commission, Faculty of Medicine, Sultan Agung Islamic University, Semarang No. 402 / VII / 2019 / Bioethics Commission.

\section{RESULTS}

The respondents in this research were students in grades 1-3 in Public Elementary School 1 Kutoharjo, Kaliwungu, Kendal, in the age group of 6-10 years, which was the age group with the highest prevalence in previous studies. The average age of the respondents was $7.69 \pm$ 0.874 years. This is because the number of grade 1 and grade 2 respondents was higher than that of grade 3 (Table 2 ).

The results of the examination of the perianal smear specimens showed that $37.33 \%$ of the students were positively infected by pinworms. The results of the examinations of their fingernails revealed that $44.00 \%$ of the students' fingernails contained pinworm eggs (Table 1).

The results of the interview respondents showed that elementary school-aged children in the PHC of Kaliwungu' working area still possess poor habits related to maintaining personal hygiene. This data indicated that $36.67 \%$ of respondents did not wash their hands with soap before eating, $56.67 \%$ of respondents did not wash their hands with soap after defecation, $49.33 \%$ of respondents did not wash their hands with soap after playing with soil, $54.67 \%$ of respondents did not cut and care for their nails well, $45.33 \%$ of respondents had the habit of biting their fingers, $28.00 \%$ of respondents had the habit of sucking their fingers, $35.33 \%$ of respondents had the habit of scratching the buttocks area, and $37.33 \%$ of respondents had the habit of defecating carelessly (Table 2).

Table 1

Frequency Distribution of Examination Results of Pinworm Egg Existence

\begin{tabular}{lrr}
\hline \multicolumn{1}{c}{ Variable } & $\mathrm{n}$ & $\%$ \\
\hline $\begin{array}{l}\text { The existence of worm eggs in } \\
\text { the perianal area }\end{array}$ & & \\
$\quad \begin{array}{l}\text { Positive } \\
\quad \text { Negative }\end{array}$ & 56 & 37.33 \\
$\begin{array}{l}\text { The existence of worm eggs on } \\
\text { hand nails }\end{array}$ & 94 & 62.67 \\
$\quad$ Positive & & \\
$\quad$ Negative & 66 & 44.00 \\
\hline Total & 84 & 56.00 \\
\hline
\end{tabular}

Public Elementary School 1 Kutoharjo students get worm medication from the PHC of Kaliwungu every February and August, but not all students take the medicine that is given. As many as $44.00 \%$ of respondents had not taken an anthelmintic within the last six months (Table 2).

The results revealed that the proportion of pinworm infections in the children who did not wash their hands with soap before eating $(67.86 \%)$ was higher than in those who washed their hands with soap before eating (32.14\%). The results of the hypothesis testing using the chi-square test obtained a p-value of 0.01 , indicating that there was a significant relationship between hand washing habits before eating and pinworm infections. Children who did not wash their hands with soap before eating were nine times more likely to be infected with pinworms than those who washed their hands with soap before eating, with a POR value of $9.56(95 \% \mathrm{CI}=4.43<\mathrm{POR}<$ 20.62) (Table 3).

The proportion of pinworm infections in the children who did not wash their hands with soap after defecation was three times greater than that in the children who washed their hands with soap. The hypothesis testing obtained a p-value of 0.01 , indicating that there is a correlation between washing hands with soap after defecation and pinworm infections in primary school-aged children. The children who did not wash their hands with soap were more likely to suffer pinworm infections, with a POR value of 4.74 $(2.22<$ POR < 10.11) (Table 3). 
Table 2

Frequency Distribution of Research Variables

\begin{tabular}{|c|c|c|}
\hline Variable & Frequency (n) & Percentage $(\%)$ \\
\hline Age (years) & \multicolumn{2}{|c|}{$6-10(7.69 \pm 0.874$ years $)$} \\
\hline \multicolumn{3}{|l|}{ Sex } \\
\hline Male & 60 & 40.00 \\
\hline Female & 90 & 60.00 \\
\hline \multicolumn{3}{|l|}{ Handwashing with soap before eating } \\
\hline No & 55 & 36.67 \\
\hline Yes & 95 & 63.33 \\
\hline \multicolumn{3}{|l|}{ Handwashing with soap after defecation } \\
\hline No & 85 & 56.67 \\
\hline Yes & 65 & 43.33 \\
\hline \multicolumn{3}{|c|}{ Handwashing with soap after playing with soil } \\
\hline No & 74 & 49.33 \\
\hline Yes & 76 & 50.67 \\
\hline \multicolumn{3}{|l|}{ Habit of using soap in the shower } \\
\hline No & 1 & 0.67 \\
\hline Yes & 149 & 99.33 \\
\hline \multicolumn{3}{|l|}{ Cutting and caring for nails } \\
\hline No & 82 & 54.67 \\
\hline Yes & 68 & 45.33 \\
\hline \multicolumn{3}{|l|}{ Finger biting } \\
\hline Yes & 68 & 45.33 \\
\hline No & 82 & 54.67 \\
\hline \multicolumn{3}{|l|}{ Finger sucking } \\
\hline Yes & 42 & 28.00 \\
\hline No & 108 & 72.00 \\
\hline \multicolumn{3}{|l|}{ Scratching buttocks area } \\
\hline Yes & 53 & 35.33 \\
\hline No & 97 & 64.67 \\
\hline \multicolumn{3}{|l|}{ Defecating carelessly } \\
\hline Yes & 56 & 37.33 \\
\hline No & 94 & 62.67 \\
\hline \multicolumn{3}{|l|}{ Take anthelmintic in the last 6 months } \\
\hline No & 66 & 44.00 \\
\hline Yes & 84 & 56.00 \\
\hline Total & 150 & 100.00 \\
\hline
\end{tabular}

The proportion of pinworm infections in the children who did not wash their hands with soap after playing with soil $(60.71 \%)$ was higher than that in the children who washed their hands with soap (39.29\%). The statistical test results acquired a p-value of 0.03 , indicating that there is correlation between hand washing habits and pinworm infections. The children who did not wash their hands with soap after playing with soil possessed a greater chance of being infected with pinworms, with a POR value of $2.09(1.06<$ POR < 4.91) (Table 3).

The proportion of pinworm infections in the children who had not taken an anthelmintic in the past six months $(57.14 \%)$ was greater than that in those who had taken an anthelmintic (42.86\%). The statistical test results showed that there is a correlation between taking worm medication and pinworm infections, with a p-value of 0.01 . The children who had not taken an anthelmintic in the past six months were more likely to be infected with pinworms, with a POR value of $2.35(1.20<$ POR < 4.63) (Table 3).

The proportion of pinworm infections in children whose nail examination results were positive for containing pinworm eggs $(62.50 \%)$ was higher than the negative results $(37.50) \%$. The presence of worm eggs on fingernails was significantly associated with pinworm infections in children with a $p$-value of 0.00 . Children who had 
positive fingernails with pinworm eggs had a greater chance of being infected with pinworms with a POR value of $3.39(1.70<$ POR < 6.76) (Table 3).

The habits of cutting and caring for fingernails, biting fingers, and finger sucking were not statistically significantly associated with pinworm infections. The proportion of pinworm infections in children who did not cut and care for their nails $(53.57 \%)$ was higher than that of those that cut and treated their nails $(46.43 \%)$. The proportion of pinworm infections in children who didn't had the habit of biting their fingers $(55.36 \%)$ was higher than that in those who had bite their fingers (44.64\%). The proportion of pinworm infections in children who didn't had finger-sucking habits $(66.07 \%)$ was higher than that of those who did not suck their fingers (33.93\%) (Table 3).

The results of the multivariate analysis acquired three main variables as determinant factors of pinworm infections, specifically in primary school-aged children in the PHC of Kaliwungu ' working area, which were washing hands with soap before eating (POR value of 6.47 [2.87 < POR < 14.59]), washing hands with soap after defecation (POR value of 3.36 [1.40 < POR < 8.05]), and taking worm medication every six months (POR value of 2.43 [1.08 < POR < 5.50]) (Table 4).

Table 3

The correlation between personal hygiene, anthelmintic consumption, and the existence of pinworm eggs on fingernails in primary school-aged children infected by pinworms in PHC of Kaliwungu' working area

\begin{tabular}{|c|c|c|c|c|c|c|}
\hline \multirow{3}{*}{ Variable } & \multicolumn{4}{|c|}{ Infected by Pinworm } & \multirow{3}{*}{$\begin{array}{c}p \\
\text { value }\end{array}$} & \multirow{3}{*}{$\begin{array}{c}\text { POR } \\
(95 \% \text { CI })\end{array}$} \\
\hline & \multicolumn{2}{|c|}{ Positive } & \multicolumn{2}{|c|}{ Negative } & & \\
\hline & $\mathrm{n}$ & $\%$ & $\mathrm{n}$ & $\%$ & & \\
\hline \multicolumn{7}{|c|}{ Washing hands using soap before eating } \\
\hline No & 38 & 67.86 & 17 & 18.09 & \multirow{2}{*}{$0,01 *$} & 9,56 \\
\hline Yes & 18 & 32.14 & 77 & 81,91 & & $(4,43<\mathrm{POR}<20,62)$ \\
\hline \multicolumn{7}{|c|}{ Washing hands using soap after defecation } \\
\hline No & 44 & 78.57 & 41 & 43.62 & \multirow{2}{*}{$0,01 *$} & 4,74 \\
\hline Yes & 12 & 21.43 & 53 & 56.38 & & $(2,22<\mathrm{POR}<10,11)$ \\
\hline \multicolumn{7}{|c|}{ Washing hands with soap after playing with soil } \\
\hline No & 34 & 60.71 & 40 & 42.55 & \multirow{2}{*}{$0,03 *$} & 2,09 \\
\hline Yes & 22 & 39.29 & 54 & 57.45 & & $(1,06<\mathrm{POR}<4,09)$ \\
\hline \multicolumn{7}{|l|}{ Using soap when bathing } \\
\hline No & 1 & 1.79 & 0 & 0.00 & \multirow{2}{*}{0,37} & 5,11 \\
\hline Yes & 55 & 98.21 & 94 & 100.00 & & $(0,20<\mathrm{POR}<127,61)$ \\
\hline \multicolumn{7}{|c|}{ Cutting and caring for fingernails at least once a week } \\
\hline No & 30 & 53.57 & 52 & 55.32 & \multirow{2}{*}{0,84} & 0,93 \\
\hline Yes & 26 & 46.43 & 42 & 44.68 & & $(0,48<\mathrm{POR}<1,81)$ \\
\hline \multicolumn{7}{|l|}{ Finger biting } \\
\hline Yes & 25 & 44.64 & 43 & 45.74 & \multirow[t]{2}{*}{0,90} & 0,96 \\
\hline No & 31 & 55.36 & 51 & 42.26 & & $(0,49<\mathrm{POR}<1,86)$ \\
\hline \multicolumn{7}{|l|}{ Finger sucking } \\
\hline Yes & 19 & 33.93 & 23 & 24.47 & \multirow[t]{2}{*}{0,21} & 1,58 \\
\hline No & 37 & 66.07 & 71 & 75.53 & & $(0,77<\mathrm{POR}<3,28)$ \\
\hline \multicolumn{7}{|l|}{ Defecating carelessly } \\
\hline Yes & 22 & 39,29 & 34 & 36.17 & \multirow[t]{2}{*}{0,70} & 1,14 \\
\hline No & 34 & 60.71 & 60 & 63.83 & & $(0,58<\mathrm{POR}<2,26)$ \\
\hline \multicolumn{7}{|c|}{ Taking anthelmintic in the last 6 months } \\
\hline No & 32 & 57.14 & 34 & 36.17 & \multirow[t]{2}{*}{$0,01 *$} & 2,35 \\
\hline Yes & 24 & 42.86 & 60 & 63.83 & & $(1,20<\mathrm{POR}<4,63)$ \\
\hline \multicolumn{7}{|c|}{ The existence of pinworms' egg in fingernails } \\
\hline Positive & 35 & 62.50 & 31 & 32.98 & \multirow[t]{2}{*}{$0,01 *$} & 3,39 \\
\hline Negative & 21 & 37.50 & 63 & 67.02 & & $(1,70<\mathrm{POR}<6,76)$ \\
\hline Total & 56 & 100.00 & 94 & 100.00 & & \\
\hline
\end{tabular}

* showed a statistically significant correlation with pinworm infections. 
Table 4

The Results of The Multivariate Analysis

\begin{tabular}{lrcr}
\hline \multicolumn{1}{c}{ Variable } & $p$ value & POR $(95 \%$ CI $)$ & Nagelkerle R square \\
\hline Washing hands with soap before eating. & 0,00 & $6,47(2,87<$ POR $<14,59)$ & 0,38 \\
Washing hands with soap after defecation. & 0,01 & $3,36(1,40<$ POR $<8,05)$ & \\
Taking an anthelmintic in the last six months & 0,03 & $2,43(1,08<$ POR $<5,50)$ & \\
\hline
\end{tabular}

\section{DISCUSSION}

The prevalence of pinworm infections in the primary school-aged children in the working area of PHC of Kaliwungu was 37.33\%. This result was similar to the results of other previous studies, which showed a prevalence of helminthiasis in primary school-aged children of $17 \%-38 \%$ (Anjarsari, 2018; Indriyati, 2015). The results indicated that pinworm infections in primary school-aged children are still relatively high and need attention. According to Chen, Yen, \& Hwang (2018), transmission of pinworms is closely related to behavioral and environmental factors. The hypothesis test results indicated that there are several variables that are significantly related to pinworm infections: washing hands with soap before eating, after defecating, and after playing with soil, the existence of pinworm eggs on fingernails, and taking worm medication every six months. The presence of pinworm eggs on a child's fingernails can be a source of pinworm infection. This confirms that the source of pinworm transmission from the hands to the mouth is through eggs that are attached to the fingernails. The habit of washing hands with soap is significantly associated with pinworm infections. The results of this study were in line with several studies that showed that the habit of washing hands with soap can prevent the transmission of pinworm infections (Syahrir \& Aswadi, 2016). The habit of washing hands with soap after defecation is associated with pinworm infections, whereby children who do not wash their hands with soap after defecation have a greater chance of being infected with pinworms. These results were in line with previous research conducted by Anjarsari (2018) that stated that pinworm infections are more common in children who do not wash their hands using soap after defecation. Pinworms live on the surface of or in feces; thus, if a child does not wash their hands with soap after defecating, pinworms can attach to the child's fingernails.

The habit of washing hands with soap before eating and after playing with soil is significantly related to pinworm infection. Children who do not wash their hands with soap before eating allow microorganisms, including pinworm eggs attached to the fingernails, to enter their body along with the food (Chen, Yen, \& Hwang, 2018). Transmission of helminthiasis can also occur when playing with soil that has been contaminated with worm eggs. These worm eggs are likely to be tucked into the nails and can be swallowed while eating (Indriyati, 2015). In research conducted by $\mathrm{Li}$ et al (2015), children who had the habit of playing with soil had a 1.65 times greater risk of being infected with pinworms than those who did not play with soil.

The sequence of washing hands using soap properly, according to Central Java Provincial Health Office (2016) is by wetting the hands, palms, and fingers thoroughly with clean running water, rubbing soap into the palms and backs of the hands and between the fingers, cleaning underneath nails, rinsing the hands with running water, and drying the hands using tissue or air.

In this recent study, the habits of cutting and caring for nails, biting fingers, sucking fingers, and defecating carelessly did not significantly correlate with pinworm infections in the primary schoolaged children. These results correlated with a study by Suraweera, Galgamuwa, Iddawela, \& Wickramasinghe (2015). However, several other studies showed that the habits of biting fingers and sucking fingers could be determinant factors of pinworm infections (Anuar, Jalilah, Norhayati, Azlin, \& Fatmah, 2016; Wang et al., 2018). A study conducted by Merad, Merbouh, Benallal, Belfodel, \& Adjmi-Hamoudi (2018) showed that the habits of biting and sucking fingers are a major risk factor for pinworm infection, which indicates that the transmission process occurs orally from hand to mouth. Children who have the habit of playing with the ground have the potential to leave dirt on their fingers and nails, including pinworm eggs that could enter their mouth when the children bite and suck their fingers. The results of a study conducted by Li et al (2015) showed that the habit of sucking on a toy or pencil can also increases the risk of being infected with pinworms, 
especially in children at a younger age. Younger children (under five years) have a habit of inserting toy objects into their mouths. This has potential as a route for transmitting helminthiasis. In this study, the habit of scratching the buttocks area was not a risk factor for pinworm infections. Other studies showed that the prevalence of pinworm infections in children who have a habit of scratching their buttocks area is higher than in those that do not. Pinworm eggs in the perianal area can move to the hands when a child scratches their buttocks area, thereby increasing the risk of pinworm infections (Dahal \& Maharjan, 2015; Wang et al., 2018).

Pinworm infections in children who had taken worm medication in the past six months were lower. Research conducted by Cholifah (2016) also showed similar results: The percentage of pinworm infections was higher in those who had never taken medicine or who took worm medicine for $>6$ months than in those who took medicine for $<6$ months. Another study conducted by Dahesh (2018) showed that children given albendazole showed negative results from eggs or adult Enterobius vermicularis worms. Similar results were revealed by Suraweera, Galgamuwa, Iddawela, \& Wickramasinghe (2015) that the consumption of anthelmintic is able to prevent pinworm infections, but this needs to be repeated two to three times at intervals of three weeks. Provision of mass worm medication must be accompanied by efforts to promote clean and healthy living behaviors to prevent reinfection cases (Chai et al., 2015).

The multivariate analysis showed that there were three variables that became the main determinants of pinworm infections in the primary school-aged children in the working area of PHC of Kaliwungu, namely the habit of washing hands before eating, the habit of washing hands after defecation, and the taking of worm medication. PHC of Kaliwungu routinely provides worm medication for the children in its working area in an effort to control helminthiasis. This effort needs to be accompanied by health promotion efforts to instill the habit of maintaining personal hygiene, especially washing hands with soap. According to Wang et al (2018), providing education to children about infectious diseases and their treatment can increase knowledge and preventative behavior. Their results showed that there was an increase in the scores of knowledge and behavior to prevent pinworm infections in the group of children who were given education.
Education should not only be delivered to the children but also to their parents and teachers. Research conducted by Taylor et al (2018) stated that a good level of parental knowledge can be a protective factor against pinworm infection. According to Moosazadeh et al (2017), education providers need to consider programs to control pinworm infections through health education programs for children, parents, and teachers. Parents and teachers' knowledge about personal hygiene practices and efforts to prevent helminthiasis can be one of the prevention efforts. Parents and teachers who have good knowledge can provide direction and motivation for children to always get used to maintaining personal hygiene. Parents are also more concerned about the health of their children and could motivate their children to take the worm medication given by schools and health centers on a regular basis.

\section{Research Limitations}

The data collection was conducted at school in the morning. Therefore, there is a possibility that the prevalence of pinworm infections in the children was higher than the results obtained. A perianal smear was carried out at school, meaning that the children had already cleaned their perianal area. The children's fingernails were also relatively clean in the morning. Only children who did not properly take care of their nails had long, black fingernails.

\section{CONCLUSION}

Pinworm infections in primary school-aged children in the working area of PHC of Kaliwungu, Kendal District, Central Java, are associated with personal hygiene and consumption of anthelmintic. Efforts to prevent pinworm infections in primary school-aged children can be done by maintaining personal hygiene, especially by washing hands with soap before eating and after defecation, and taking worm medication at least once every six months. Health centers need to do monitoring to ensure that the worm medication that have been distributed are actually taken by the children. In addition, health centers need to work with schools and parents to continue giving children an awareness of maintaining personal hygiene, especially the habit of washing hands with soap before eating and after defecation. 


\section{CONFLICT OF INTEREST}

The authors declare that no conflict of interest in this study.

\section{AUTHOR CONTRIBUTION}

The authors would like to thank the Indonesian Ministry of Research, Technology, and Higher Education, which provided research grants, and the Higher Education Service Institution (LLDIKTI) Region VI, Department of Research and Community Service of Sekolah Tinggi Ilmu Kesehatan Kendal, which provided support towards this recent study.

\section{ACKNOWLEDGMENT}

The authors would like to thank The Indonesian Ministry of Research, Technology, and Higher Education who have provided research grants ; The Higher Education Service Institution (LLDIKTI) Region VI, Department of Research and Community Service of Sekolah Tinggi Ilmu Kesehatan Kendal who have provided support towards this recent study.

\section{REFFERENCES}

Ali, S., Amiri, N., Rahimi, M. T., Mahdavi, S. A., Moosazadeh, M., Ramzani, O., ... Siyadatpanah, S. A. (2016). Prevalence of enterobius vermicularis infection among preschool children, Babol, North of Iran. Journal of Parasitic Diseases, 40(4), 15581562. https://doi.org/10.1007/s12639-015$0727-4$

Anjarsari, M. D. (2018). Personal hygiene kejadian enterobiasis siswa sekolah dasar negeri. Higeia, 2(3), 441-452.

Anuar, T. S., Jalilah, L., Norhayati, M., Azlin, M. Y., \& Fatmah, M. S. (2016). New insights of enterobius vermicularis infection among preschool children in an urban area in Malaysia. Helminthologia, 53(1), 76-80. https://doi.org/10.1515/helmin-2015-0077

Berger, S. (2018). Enterobiasis: globala status. California, USA: GIDEON Informatics.

Central Java Provincial Health Office. (2016). Health profile of Central Java Province at 2015. Semarang.

Chai, J., Yang, S. K., Kim, J. W., Choi, S., Song, G., Jung, B., ... Tin, H. H. (2015). High prevalence of enterobius vermicularis infection among schoolchildren in three townships around Yangon , Myanmar. Korean Journal of Parasitology, 53(6), 771775.

Chen, K., Yen, C., \& Hwang, K. (2018). Enterobius vermicularis infection and its risk factors among pre-school children in Taipei, Taiwan. Journal of Microbiology, Immunology and Infection, 51(4), 559-564. https://doi.org/10.1016/j.jmii.2016.12.013

Cholifah, N. (2016). Promosi kesehatan dalam pemberian minum obat cacing dan kejadian kecacingan. JIKK, 7(1), 24-29.

Dahal, T., \& Maharjan, M. (2015). Pinworm (enterobius vermicularis ) infection in Children of Barbhanjyang VDC, Tanahun District, Nepal. Journal of Institue of Science and Technology, 20(2), 18-21.

Dahesh, S. M. A. (2018). Evaluation of a deworming campaign by albendazole during 2016 in a rural area of Giza Governorate , Egypt. Parasitologists United Journal, 11(1), 52-61.

https://doi.org/10.21608/puj.2018.1913.1005

Doni, N. Y., Zeyrek, F. Y., Simsek, Z., Gurses, G., \& Sahin, I. (2015). Risk factors and relationship between intestinal parasites and the growth retardation and psychomotor development delays of children in Şanlıurfa,

Turkey. Intestinal Parasites and Developmental Delays, 39(1), 270-276. https://doi.org/10.5152/tpd.2015.3620

Hadidjaja, P., \& Margono, S. S. (2011). Dasar parasitologi klinik. Jakarta: Badan Penerbit FKUI.

Indriyati, L. (2015). Gambaran faktor resiko kecacingan pada Anak Sekolah Dasar di Kota Banjarmasin The Overview of Helminthiasis Risk Factor of Elementary School Children In Banjarmasin City. 9(1), 21-28.

Li, H.-M., Zhou, C.-H., Li, Z.-S., Deng, Z.-H., Ruan, C.-W., Zhang, Q.-M., \& Zhu, T.-J. (2015). Risk factors for enterobius vermicularis infection in risk factors for enterobius vermicularis infection in children in Gaozhou, Guangdong, China. Infectious Diseases of Poverty, 4, 1-8. https://doi.org/10.1186/s40249-015-0058-9

Maryanti, E., Wahyuni, D., Ernalia, Y., Haslinda, L., \& Lesmana, S. D. (2017). Hubungan enterobiasis dengan status gizi pada anak di dua panti asuhan Pekanbaru. Jurnal Kesehatan Melayu, 1(1), 1-4.

Merad, Y., Merbouh, A., Benallal, K., Belfodel, S., \& Adjmi-Hamoudi, H. (2018). Prevalence 
of enterobiasis among urban school children in Sidi-bel-Abbes, Algeria. International Journal of Innovation and Applied Studies, 24(2), 453-458.

Ministry of Health RI. (2017). Minister of health RI number 15 of 2017 concerning the worms prevention. Jakarta: Ministry of Health RI.

Moosazadeh, M., Abedi, G., Afshari, M., Mahdavi, S. A., Farshidi, F., \& Kheradmand, E. (2017). Prevalence of enterobius vermicularis among children in Iran: a systematic review and meta-analysis. Osong Public Health and Research Perspectives, 8(2), 108-115.

Pebriyani, E., Adrial, \& Nofita, E. (2019). Hubungan personal hygiene dengan kejadian enterobiasis pada anak usia 6-12 tahun di panti asuhan Kota Padang. Jurnal Kesehatan Andalas, 8(1), 81-88.

Suraweera, O. S. A., Galgamuwa, L. S., Iddawela, D., \& Wickramasinghe, S. (2015). Prevalence and associated factors of enterobius vermicularis infection in children from a poor urban community in Sri Lanka : a cross-sectional study. International Journal of Research in Medical Sciences, 3(8), 1994$1999 . \quad$ https://doi.org/10.18203/23206012.ijrms20150315

Syahrir, S., \& Aswadi. (2016). Faktor yang berhubungan dengan kejadian kecacingan pada siswa SDN Inpres no . 1 Wora Kecamatan Wera Kabupaten Bima. Higiene, 2(1), 41-48.

Taylor, A., Saichua, P., Rhongbutsri, P., Tiengtip, R., Kitvatanachai, S., \& Taylor, W. R. J. (2018). A preliminary epidemiological study of pinworm infection in Thaklong Municipal Early Childhood Development Center and Rangsit Babies' Home , Pathum Thani, Thailand. BMC Research Notes, 11, 1-6. https://doi.org/10.1186/s13104-018-3708-8

Wang, M., Han, X., Fang, H., Xu, C., Lin, X., Xia, S., ... Tao, H. (2018). Impact of health education on knowledge and behaviors toward infectious diseases among students in Gansu Province, China. BioMed Research International, 2018, 1-12. 